\title{
Growth, nitrogen utilization and biodiesel potential for two chlorophytes grown on ammonium, nitrate or urea
}

\section{Authors: Everett Eustance, Robert D. Gardner, Karen M. Moll, Joseph Menicucci, Robin Gerlach, \& Brent M. Peyton.}

NOTICE: The final publication is available at Springer via http://dx.doi.org/10.1007/ s10811-013-0008-5.

Eustance E, Gardner RD, Moll KM, Menicucci J, Gerlach R, Peyton BM, "Growth, nitrogen utilization and biodiesel potential for two chlorophytes grown on ammonium, nitrate or urea," Journal of Applied Phycology 2013 25:1663-1677 


\title{
Growth, nitrogen utilization and biodiesel potential for two chlorophytes grown on ammonium, nitrate or urea
}

\author{
Everett Eustance, Robert D. Gardner, Karen M. Moll, Joseph Menicucci, Robin \\ Gerlach, and Brent M. Peyton
}

E. Eustance :R. D. Gardner:R. Gerlach :B. M. Peyton

Department of Chemical and Biological Engineering and Center for Biofilm Engineering, Montana State University, Bozeman, MT 59717, USA K. M. Moll

Department of Microbiology and Center for Biofilm Engineering, Montana State University, Bozeman, MT 59717, USA

J. Menicucci

Department of Chemical Engineering, Nazarbayev University, Astana 010000, Kazakhstan

\begin{abstract}
Nitrogen removal from wastewater by algae pro-vides the potential benefit of producing lipids for biodiesel and biomass for anaerobic digestion. Further, ammonium is the renewable form of nitrogen produced during anaerobic digestion and one of the main nitrogen sources associated with wastewater. The wastewater isolates Scenedesmus sp. 131 and Monoraphidium sp. 92 were grown with ammoni-um, nitrate, or urea in the presence of $5 \% \mathrm{CO}_{2}$, and ammonium and nitrate in the presence of air to optimize the growth and biofuel production of these chlorophytes. Results showed that growth on ammonium, in both $5 \% \mathrm{CO}_{2}$ and air, caused a significant decrease in $\mathrm{pH}$ during the exponential phase causing growth inhibition due to the low buffering capacity of the medium. Therefore, biological buffers and $\mathrm{pH}$ controllers were utilized to prevent a de-crease in $\mathrm{pH}$. Growth on ammonium with $\mathrm{pH}$ control (synthetic buffers or $\mathrm{KOH}$ dosing) demonstrated that growth (rate and yield), biodiesel production, and ammonium utilization, similar to nitrate- and urea-amended treatments, can be achieved if sufficient $\mathrm{CO}_{2}$ is available. Since the use of buffers is economically limited to laboratory-scale experi-ments, chemical $\mathrm{pH}$ control could bridge the gap encountered in the scale-up to industrial processes.
\end{abstract}

Keywords: Biodiesel $\cdot$ Fatty acid methyl ester $($ FAME) $\cdot$ Algae $\cdot$ Wastewater $\cdot$ Nitrogen removal $\cdot$ pH Control

\section{Introduction}

Algae have potential to provide economically viable alterna-tive energy in the form of lipids and synthesis gas derived from leftover biomass. However, algae require large amounts of nitrogen during growth, and increases in fertilizer prices might offset some potential biofuel production (Lundquist et al. 2010; Sialve et al. 2009). Nitrate, ammonium and urea can be utilized as nitrogen sources in algal growth systems, and ammonium is the basic unit of nitrogen required by algae to produce amino acids. Therefore, in a mixed nitrogen source medium, ammonium is usually preferentially utilized over nitrate or urea (Dortch 1990; Fernández et al. 2004; Molloy and Syrett 1988). Furthermore, ammonium and urea account for 40 and $60 \%$ of the nitrogen in municipal wastewater, respectively, and have been identified as being viable for scaled industrial systems (Lundquist et al. 2010; Sedlak 1991). However, research focused on algal growth using ammonium is typically limited to nitrogen removal during wastewater treatment and provides little insight in terms of biofuel production.

Nitrogen utilization for algae is estimated to be 55 to 111 times the nitrogen required for terrestrial-based crops on a per hectare per year basis, due to increased productivity (Sialve et al. 2009). Hence, large-scale growth facilities will require nitrogen recycling or an inexpensive nitrogen source such as wastewater to reduce nitrogen costs (Christenson and Sims 2011; Sialve et al. 2009). Ammonium is most easily regenerated from algal biomass after lipid extraction and has been suggested as one of the few viable nitrogen sources for large-scale algae production (Lundquist et al. 2010; Sialve et al. 2009). 
Nitrogen regeneration is accomplished through the degradation of proteins during secondary processing of biomass. Anaerobic digestion is one of the most beneficial methods for nitrogen regeneration since methane and $\mathrm{CO}_{2}$ are produced from the biomass and proteins are degraded to produce ammonium (Christenson and Sims 2011; de Boer et al. 2012). Methane production increases overall energy yields, while the $\mathrm{CO}_{2}$ and ammonium can be recycled into the phototrophic algal system to increase growth and reduce substrate costs.

Growth on ammonium has been documented for various algae strains, but limitations have also been reported including lower growth rates and lipid productivity when compared to growth on nitrate (Bongers 1956; Chen et al. 2011; Dvořáková-Hladká 1971; Li et al. 2008; Ludwig 1938; Pavlova et al. 1994; Thacker and Syrett 1972; Xin et al. 2010). Decreases in algae growth utilizing ammonium are attributed to three phenomena: (1) Algae growth on ammonium translocates a proton out of the cell to maintain cell neutrality during uptake of the cation, thus decreasing the pH of the medium (Fuggi et al. 1981; Goldman and Brewer 1980; Xin et al. 2010). The acidification of the medium can inhibit cell growth. (2) Cell growth on low concentration of $\mathrm{CO}_{2}$ (air $\sim 0.04 \% \mathrm{CO}_{2}$ ) can cause algae cells to preferentially utilize carbon for anaplerotic reactions instead of photosynthetic reactions required for growth. This is due to phosphoenolpyruvate carboxylase (PEPC) having a greater affinity for inorganic carbon than ribulose bisphosphate carboxylase oxygenase (RUBISCO; Amory et al. 1991; Di Martino Rigano et al. 1986; Elrifi et al. 1988; Fernández et al. 2004; Guy et al. 1989; Norici and Giordano 2002; Vanlerberghe et al. 1990). The allocation of carbon towards anaplerotic reactions decreases the cell's efficiency and therefore gives a lower growth rate. (3) Algae growth on ammonium at alkaline $\mathrm{pH}$ values $(>8)$ can result in growth inhibition due to the presence of free ammonia (Abeliovich and Azov 1976; Azov and Goldman 1982). High concentrations of free ammonia $(>0.5 \mathrm{mM})$ have been shown to reduce the carbon uptake rate of the cell reducing the growth rate. Such reductions in growth rate can be eliminated by maintaining the $\mathrm{pH}$ well below the $\mathrm{pK}_{\mathrm{a}}$ of the ammonium/ammonia system $(\mathrm{pH} 9.3)$ and by increasing the $\mathrm{CO}_{2}$ concentration in the medium.

Here, we report on the growth of two distinctly different chlorophytes isolated from domestic wastewater treatment ponds. Our focus was to determine optimized environmental conditions for growth and biodiesel production with different nitrogen sources (nitrate, urea and ammonium) and different $\mathrm{CO}_{2}$ concentrations (air or air supplemented with $\left.5 \% \mathrm{CO}_{2}\right)$. Further, this work elucidates approaches to improving nitrogen utilization and growth rates using ammonium, with the intention of becoming comparable to nitrate and urea in order to improve the feasibility of industrial-scale algal growth on ammonium.

\section{Materials and methods}

Organism isolation and culturing

Two chlorophytes, Scenedesmus sp. 131 (strain 131) and Monoraphidium sp. 92 (strain 92), were isolated from wastewater settling ponds in Deer Lodge, Montana, USA. The strains were first identified as unialgal by morphology, and genus level identification was made using key morphological markers to identify Scenedesmus sp. 131 and Monoraphidium sp. 92 (Marvan et al. 1984; Prescott 1978; Trainor et al. 1976). Further identification was completed by sequencing the SSU $18 \mathrm{~S}$ RNA gene using the NCBI BLAST database. Scenedesmus sp. 131 shows $>99 \%$ alignment to Scenedesmus communis and Monoraphidium sp. 92 shows $>99 \%$ alignment to Monoraphidium minutum strain AS3-5.

Both strains were grown in Bold's Basal medium (BBM) with the $\mathrm{pH}$ adjusted to 7.8 using $\mathrm{KOH}$ (Bischoff and Bold 1963). This medium was modified for different nitrogen source experiments by replacing the sodium nitrate $(2.94 \mathrm{mM})$ with either urea $(1.47 \mathrm{mM})$ or ammonium chloride $(2.94 \mathrm{mM})$, which were filter sterilized $(0.2 \mu \mathrm{m})$ into the autoclaved medium after it reached room temperature. Experiments with ammonium were conducted unbuffered or buffered with $8 \mathrm{mM}$ Piperazine-1,4-bis(2-ethanesulfonic acid) (PIPES, $\mathrm{pK}_{\mathrm{a}} 6.8$ ) or $N$-(2-hydroxyethyl)piperazine- $N$ '-(2ethanesulfonic acid) (HEPES, $\mathrm{pK}_{\mathrm{a}}$ 7.5) depending on the desired pH (Sigma-Aldrich, St. Louis MO). Biological triplicate cultures were grown using a 14:10 light/dark cycle $\left(350 \mu \mathrm{mol}\right.$ photons $\left.\mathrm{m}^{-2} \mathrm{~s}^{-1}\right)$ at room temperature $\left(24 \pm 1^{\circ} \mathrm{C}\right)$ in previously described vertical tubular photobioreactors (diameter $=70 \mathrm{~mm}$, height $=500 \mathrm{~mm}$ ) filled with $1 \mathrm{~L}$ of BBM (Gardner et al. 2012). The reactors were modified for $\mathrm{pH}$ control by the addition of an inlet port for base and a slot for an autoclavable $\mathrm{pH}$ probe (Cole-Parmer, Vernon Hills IL). The probe was attached to a $\mathrm{pH}$ controller (HANNA Instruments BL 931700-1,) with a minimum $\mathrm{pH}$ set point, to activate a dosing pump (HANNA Instrument BL 1.5-1) with $0.1 \mathrm{M} \mathrm{KOH}$. The aeration and ventilation ports were equipped with $0.2-\mu \mathrm{m}$ filters (Millipore) to prevent contamination or release of algae. The reactors were sparged with $400 \mathrm{~mL} \mathrm{~min}^{-1}$ air or air with $5 \% \mathrm{CO}_{2}(v / v)$. Pure $\mathrm{CO}_{2}$ was mixed with compressed house air, run through a water/oil trap, and an electronic on/off controller was utilized to turn on the $\mathrm{CO}_{2}$ during the light and off during the dark cycle.

Analysis of media components

The $\mathrm{pH}$ of the medium was measured using a standard bench top meter. Concentrations of phosphate, sulfate, and nitrate were measured by ion chromatography (IC) using an IonPac AS9-HC Anion-Exchange Column (Dionex) with a 9.0-mM 
sodium carbonate buffer at a flow rate of $1.0 \mathrm{~mL} \mathrm{~min}{ }^{-1}$. Detection was performed using a CD20 conductivity detector (Dionex) at $21{ }^{\circ} \mathrm{C}$, and IC data were analyzed on Dionex PeakNet 5.2 software. Phosphate and sulfate concentrations were measured by IC to confirm they were present in excess during experimentation.

Concentrations of ammonium were measured by IC using a Metrosep C4 150/4.0 mm IC column (Metrohm) using an Agilent 1100 series liquid chromatograph controlled to $25^{\circ} \mathrm{C}$ with dipicolinic acid solution as the eluent at a flow rate of

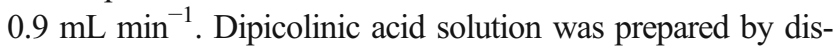
solving $0.1170 \mathrm{~g}$ of 2,6-pyridinedicarboxylic acid (>99.5\% purity for ion chromatography, Sigma-Aldrich) and $0.101 \mathrm{~mL}$ of $67-70 \%$ trace metal grade nitric acid (Fisher Scientific) into $1 \mathrm{~L}$ of nanopure water $(18 \mathrm{M} \Omega)$. Detection was performed using a 732 IC detector (Metrohm). Data were analyzed using Agilent ChemStation software (Rev. B.02.01-SR1). Low levels of ammonium $\left(<2 \mathrm{mg} \mathrm{L}^{-1} \mathrm{NH}_{4}^{+}\right)$during the final time points of experiments on air with HEPES or PIPES were monitored using a modified Nessler assay (Roon and Levenberg 1968) performed in a 96-well plate. To each $250-\mu \mathrm{L}$ sample (analyzed in triplicate), $3 \mu \mathrm{L}$ of mineral stabilizer $(\mathrm{HACH})$ and polyvinyl alcohol $(\mathrm{HACH})$ were added prior to adding $10 \mu \mathrm{L}$ of Nessler reagent (HACH) to each well. Samples were analyzed using a Multiskan Spectrum with Skanit software (Thermo Fisher Scientific).

Concentrations of urea were measured using an Agilent 1100 series HPLC equipped with a Zorbax Eclipse XDBC18 column $(4.6 \times 150 \mathrm{~mm}, 5 \mu \mathrm{m}$ Agilent Technologies $)$ controlled to $35{ }^{\circ} \mathrm{C}$. A gradient of two eluents $[20 \mathrm{mM}$ sodium acetate (ACS reagent, Sigma-Aldrich) containing $10 \%$ acetonitrile (HPLC Grade, Burdick and Jackson) and $100 \%$ acetonitrile] was utilized at $1.0 \mathrm{~mL} \mathrm{~min}{ }^{-1}$ as described by Clark et al. (2007). Detection was performed at $230 \mathrm{~nm}$ using an Agilent 1100 series UV-visible diodearray detector. Samples were derivatized (xanthydrol derivatization) using an Agilent 1100 series autosampler (Clark et al. 2007). Data were analyzed using Agilent ChemStation software (Rev. A.10.02).

\section{Biomass yield}

Cell yields with respect to nitrogen utilization $\left(Y_{\mathrm{X} / \mathrm{N}}\right)$ were calculated using Eq. 1 by dividing the change in dry cell weight (DCW) by the nitrogen consumed during the experiment.

$Y_{\mathrm{X} / \mathrm{N}}=\frac{X_{f}-X_{i}}{C_{\mathrm{N}, i}-C_{\mathrm{N}, f}}$

Where $X$ is DCW [gram biomass (liter medium) ${ }^{-1}$ ], $C_{\mathrm{N}}$ is nitrogen concentration [gram nitrogen (liter medium) ${ }^{-1}$ ] and subscripts $i$ and $f$ represent initial and final values, respectively. Calculations based on this equation assumed the initial biomass concentration was insignificant compared to the final DCW. The nitrogen consumed is based on the change in concentration of nitrogen in the medium.

Biodiesel potential measured by gas chromatography

Biodiesel potential of algal cells was analyzed using direct transesterification based on the protocol of Griffiths et al. (2010). Biodiesel potential is defined as the mass of fatty acid methyl esters (FAME) created from a known amount of dry biomass, thus representing the portion of the cell that can be utilized for biodiesel production as shown in Eq. 2 and is an updated term that was previously described as biofuel potential by Gardner et al. (2013).

Biodiesel potential $=\frac{\text { gram FAME }}{\text { gram dry biomass }}$

Biodiesel potential, as defined here, provides a measure of the capability of the cell to produce biodiesel; however, the overall productivity of the system depends on the amount of algal biomass produced. Therefore, in contrast to biodiesel potential, the biodiesel content is defined here as the total concentration of FAMEs [gram FAME (liter culture) ${ }^{-1}$ ] that could be produced from the algal cultures. Biodiesel content is calculated using Eq. 3 and is found by multiplying the biodiesel potential by the DCW at the time of harvest.

Biodiesel content $=$ Biodiesel potential $\times$ DCW

To determine biodiesel potential, $10 \mathrm{mg}$ of lyophilized biomass was added to a $5-\mathrm{mL}$ glass serum vial with $1.0 \mathrm{~mL}$ toluene. Sodium methoxide ( $2 \mathrm{~mL}$; Pure, ACROS) was added to the mixture prior to crimp sealing with Teflonlined septa and vortexing. Samples were reacted at $80^{\circ} \mathrm{C}$ for $30 \mathrm{~min}$ with intermittent vortexing ( every $5 \mathrm{~min}$ ) and cooled for $10 \mathrm{~min}$ before $2 \mathrm{~mL}$ of $14 \% v / v$ boron trifluoride in methanol $\left(\mathrm{BF}_{3}\right.$-methanol, Thermo Scientific) was added, and the reaction cycle was repeated. Vials were cooled to room temperature for $10 \mathrm{~min}$ before adding $0.8 \mathrm{~mL} \mathrm{H}_{2} \mathrm{O}$ and $0.8 \mathrm{~mL}$ hexane (GC grade, Fisher Scientific). Samples were vortexed and centrifuged at $3,000 \times g$ for $5 \mathrm{~min}$ before the upper hexane/toluene layer containing the FAME extract was transferred to vials for appropriate dilution with triple solvent (chloroform (HPLC grade, EMD)/tetrahydrofuran (HPLC grade, Fisher Scientific)/hexane, 1:1:1 by volume). Prior to gas chromatography (GC) analysis, $10 \mu \mathrm{L}$ of $10 \mathrm{mg}$ $\mathrm{mL}^{-1}$ octacosane was added as an internal standard to $1 \mathrm{~mL}$ of diluted sample in a $1.5-\mathrm{mL}$ GC autosampler vial before being capped with a Teflon-lined septum. Samples $(1 \mu \mathrm{L})$ were injected into an Agilent $6890 \mathrm{~N} \mathrm{GC}$ and quantified with a flame ionization detector using a $250 \mu \mathrm{m} \times 15 \mathrm{~m}$ Restek RTX65TG column (fused silica with a film thickness 
of $0.1 \mu \mathrm{m}$; Restek, USA). The oven temperature increased from 60 to $370{ }^{\circ} \mathrm{C}$ at a rate of $10^{\circ} \mathrm{C} \mathrm{min}{ }^{-1}$ using helium as the carrier gas at a pressure of $61.2 \mathrm{kPa}$ and a flow rate of $1.3 \mathrm{~mL} \mathrm{~min}^{-1}$. A split mode with a ratio of 1:30.8 was used for analysis of FAMEs from direct transesterification reactions. Palmitic acid methyl ester, nonadecanoic acid methyl ester, glyceryl tripalmitin, and glyceryl tristearin (all from Sigma-Aldrich) were used as calibration standards at a concentration range of 0.001 to $2 \mathrm{mg} \mathrm{mL}^{-1}$. Peak areas for standards were determined using Agilent ChemStation software (Rev. B.02.01-SR1), and comparison with standards allowed for calculation of sample concentrations. PAME and NAME had retention times of approximately 17.9 and 20.2 min, respectively. Therefore, PAME was used as the standard for peaks between 16 and $19 \mathrm{~min}$, and NAME was used as the standard for peaks between 20 and $25 \mathrm{~min}$. It is important to note that very few peaks occurred above $23.5 \mathrm{~min}$ and no peaks occurred in the region of glyceryl tripalmitin and glyceryl tristearin indicating complete conversion to FAMEs.

\section{Cell concentrations and harvesting}

Algae cells were counted directly using a hemacytometer with a minimum of 400 cells counted for statistical reliability (Andersen 2005). Micrographs of cell morphology were taken using a transmitted light microscope (Nikon Eclipse E800) with an Infinity 2 color camera for comparison between consecutive experiments. Cells were harvested at the end of each experiment by centrifugation $(4,000 \times \mathrm{g}$ for $10 \mathrm{~min})$ of $750 \mathrm{~mL}$ of the reactor contents $(3 \times 250 \mathrm{~mL}$ bottles $)$, washed once, and frozen at $-80{ }^{\circ} \mathrm{C}$ for lyophilization. An additional $25 \mathrm{~mL}$ was collected from each reactor and filtered, using $0.7-\mu \mathrm{m}$ glass fiber filters (Fischer Scientific), to determine DCW. The filters with algae were dried in an oven at $60{ }^{\circ} \mathrm{C}$ until the weight of the biomass and filter remained constant. DCWs [gram biomass (liter medium) $)^{-1}$ ] were calculated by subtracting the dry weight of the clean filter from the ovendried weight of the filter with biomass and dividing by the volume of sample filtered.

\section{Results}

Comparison of growth on different nitrogen sources with $5 \% \mathrm{CO}_{2}$ gas sparge

Comparison of three different nitrogen sources for both strains (131 and 92) was carried out using BBM with either sodium nitrate $(2.94 \mathrm{mM})$ or with the molar nitrogen equivalent of ammonium $(2.94 \mathrm{mM})$ or urea $(1.47 \mathrm{mM})$. To ensure there were no carbon limitations during exponential growth, the strains were grown on air supplemented with
$5 \% \mathrm{CO}_{2}$. Figure 1 shows $(\mathrm{a}, \mathrm{b})$ nitrogen concentrations $(\mathrm{mM}-\mathrm{N}),(\mathrm{c}, \mathrm{d}) \mathrm{pH}$ of the medium and $(\mathrm{e}, \mathrm{f})$ cell concentration over time for both strains. Strains 131 and 92 utilized nitrate and urea by 6 days, and the cells grew exponentially for approximately 6 days when growth slowed and ceased due to nitrogen limitation. Initially (0-2 days), for strain 131 grown on nitrate, acidification of the medium occurred, presumably due to an increase in carbonic acid from the $5 \% \mathrm{CO}_{2}$ sparge and a lack of sufficient aeration time prior to inoculation for the medium to equilibrate to the increased $\mathrm{CO}_{2}$ concentration. After which, the medium $\mathrm{pH}$ increased from 6.5 to near 7 due to the uptake of nitrate. Growth on urea maintained a relatively stable $\mathrm{pH}$ due to the lack of ionic charge.

When strains 131 and 92 were grown on ammonium, there was an initial utilization similar to nitrate- and ureaamended cultures along with exponential growth for 3 and 4 days, respectively. Acidification of the unbuffered medium was observed (Fig. 1c, d), which presumably caused growth inhibition and chlorophyll degradation (Fig. 2). Figure 1 also indicates that strain 131 was not as tolerant to low $\mathrm{pH}$ values as strain 92, based on the more rapid decrease in live cell numbers. In contrast to growth on nitrate and urea, growth on ammonium exhibited a $\mathrm{pH}$ decrease, which most likely inhibited growth and prevented complete utilization of ammonium for both strains. The large error bars in $\mathrm{pH}$ measurements of strain 131 in the presence of ammonium between 3 and 6 days are due to one reactor with a $\mathrm{pH}$ mean of 3.8 during that time range, while the other two reactors had a $\mathrm{pH}$ mean of 5.1.

Tables 1 and 2 summarize the DCW at time of harvest, specific growth rate, biomass yield, biodiesel potential, and biodiesel content for strains 131 and 92 when grown under different nitrogen, aeration, and buffering conditions. Both strains had the highest DCW when grown on nitrate, and the final DCW on ammonium was significantly lower most likely due to inhibition by low $\mathrm{pH}$ preventing further growth.

Tables 1 and 2 show that the greatest biodiesel potential was achieved for strains 131 and 92 when they were grown on $5 \% \mathrm{CO}_{2}$ in the presence of urea and nitrate, respectively. However, both strains had the highest biodiesel content on nitrate, emphasizing the importance of increased DCW in assessing the biodiesel content. The low biomass concentrations obtained with unbuffered ammonium compared to nitrate or urea indicate a significantly decreased viability of biodiesel production from algae on ammonium without $\mathrm{pH}$ control.

Growth on air with nitrate or ammonium

To analyze the combined effects of $\mathrm{pH}$ and carbon limitation, along with nitrogen utilization, strains 131 and 92 were grown on nitrate or ammonium and aerated with ambient air 
Fig. 1 Mean and range (error bars) of $\mathbf{a}, \mathbf{b}$ medium nitrogen concentration ( $\mathrm{mM}$ $\mathrm{N}), \mathbf{c}, \mathbf{d ~ p H}$, and $\mathbf{e}, \mathbf{f}$ live cell density for triplicate cultures of a, c, e Scenedesmus sp. 131 and b, d, f Monoraphidium sp. 92 grown on $5 \% \mathrm{CO}_{2}$ gas sparge using nitrate (square), ammonium (filled triangle), or urea (filled diamond) as the nitrogen source

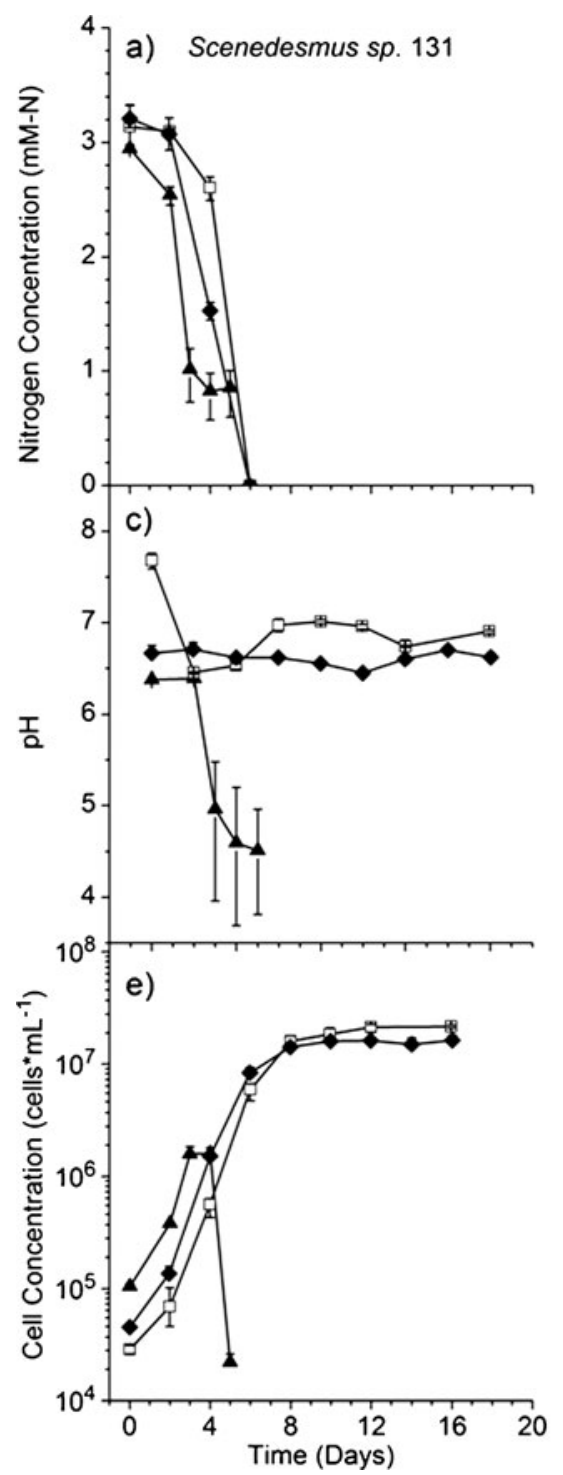

$\left(0.04 \% \mathrm{CO}_{2}\right)$. Figure 3 shows $(\mathrm{a}, \mathrm{b})$ nitrogen concentrations $(\mathrm{mM}-\mathrm{N}),(\mathrm{c}, \mathrm{d}) \mathrm{pH}$ of the medium and $(\mathrm{e}, \mathrm{f})$ cell concentration over time for both strains. Growth on nitrate caused the $\mathrm{pH}$ to increase, and the change in growth rates indicated that carbon limitation most likely occurred. In contrast, growth on ammonium showed a significant $\mathrm{pH}$ decrease to 4.3 for strain 131 and 4.5 for strain 92, most likely due to the release of protons during ammonium assimilation. Figure 3 also shows that neither strain fully utilized the available ammonium, presumably due to inhibition at low $\mathrm{pH}$ values. The air sparged cultures grew for approximately 14 days on ammonium before cell concentrations decreased. In contrast, these strains exhibited 4 days of growth before a subsequent decrease in observed cell density when sparged with $5 \% \mathrm{CO}_{2}$ (Fig. 1). Large standard deviations for the cell concentrations of strain 131 grown on ammonium on days 15 and 16 were due to a lower cell count in one culture that exhibited cell death prior to the other two.

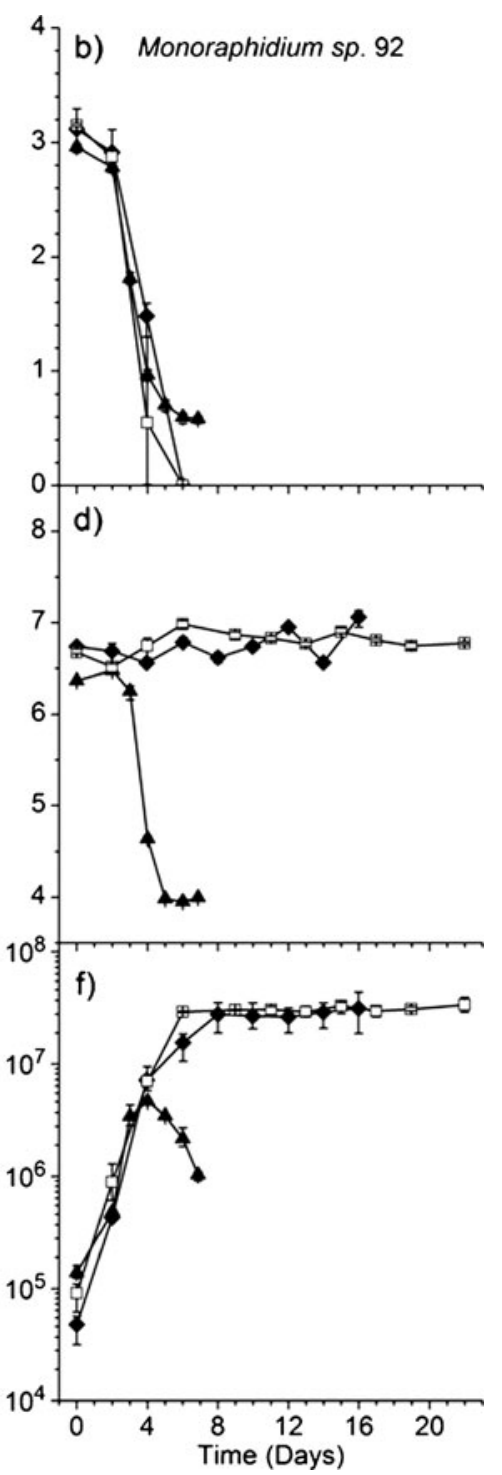

Both strain 131 (Table 1) and strain 92 (Table 2) achieved lower DCWs when grown on nitrate with air in comparison to $5 \% \mathrm{CO}_{2}$. For the air only systems, this is attributed to the increase in $\mathrm{pH}$ and potential carbon limitation. Further, strain 131 had an increased biodiesel potential when grown on nitrate with air compared to $5 \% \mathrm{CO}_{2}$, while strain 92 had decreased biodiesel potential. However, higher $\mathrm{CO}_{2}$ concentrations increased the final DCW of both strains causing an increase in biodiesel content. This demonstrates the importance of increasing DCW in addition to the biodiesel potential of algal cells.

Tables 1 and 2 also emphasize the importance of $\mathrm{pH}$ control associated with growing cultures on ammonium as compared to nitrate. For both strains grown on ammonium with either ambient air or $5 \% \mathrm{CO}_{2}$, the $\mathrm{pH}$ of the system decreased significantly causing growth inhibition, which prevented full utilization of the available nutrients, thus decreasing the final DCW, biodiesel potential, and the biodiesel content. 
Fig. 2 Micrographs for Monoraphidium sp. 92 (top) and Scenedesmus sp. 131 (bottom) over consecutive sampling time points.

Ammonium was the nitrogen source, and the medium was sparged with $5 \% \mathrm{CO}_{2}$
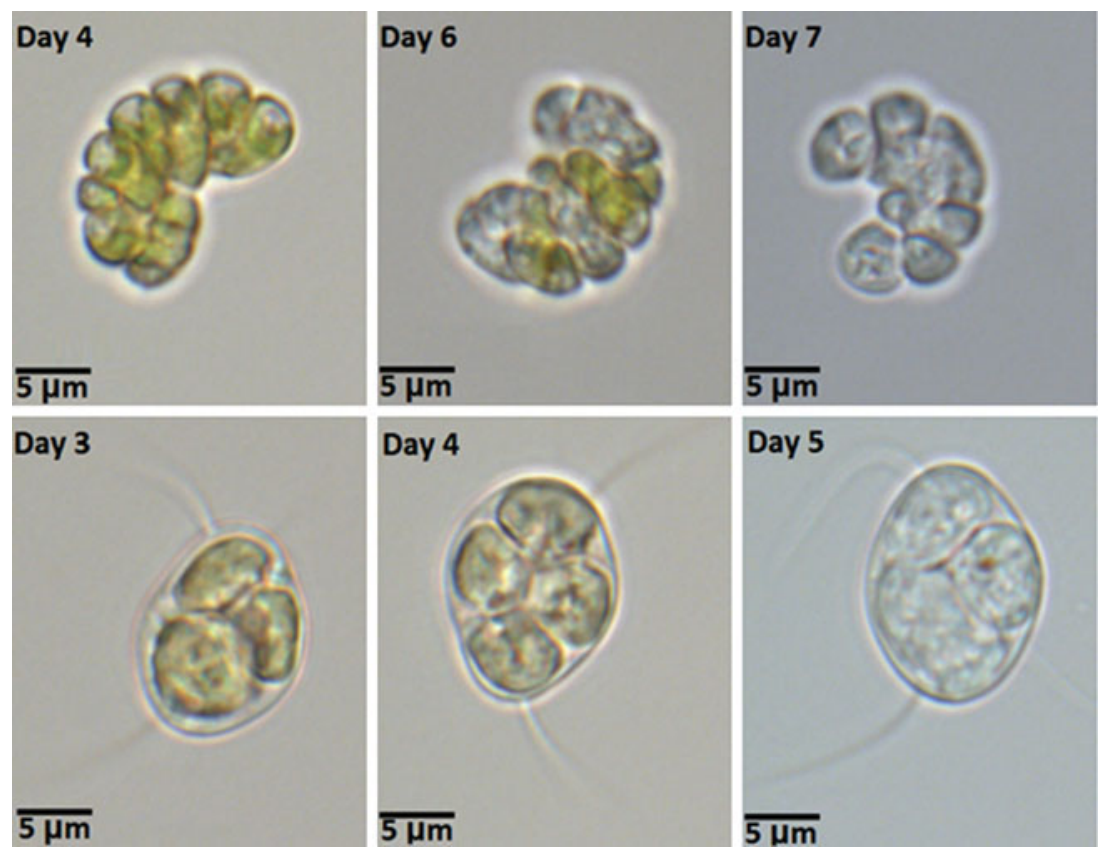

Growth on ammonium with synthetic buffers and ambient aeration

To prevent the decrease in $\mathrm{pH}$ and the resulting loss of cell viability during growth on ammonium, $8 \mathrm{mM}$ of synthetic buffer PIPES $\left(\mathrm{pK}_{\mathrm{a}} 6.8\right)$ or HEPES $\left(\mathrm{pK}_{\mathrm{a}}\right.$ 7.5) was added to maintain a more constant $\mathrm{pH}$. A concentration of $8 \mathrm{mM}$ was chosen because it was over twice the concentration of protons potentially being released from the cells during ammonium assimilation. The two synthetic buffers were used to address the question of whether a specific buffer interfered with growth and thus allowed for a better understanding of the $\mathrm{pH}$ influence in DIC limiting conditions. Figure 4 shows $(a, b)$ nitrogen concentrations $(\mathrm{mM}-\mathrm{N}),(\mathrm{c}, \mathrm{d}) \mathrm{pH}$ of the medium, and $(\mathrm{e}, \mathrm{f})$ cell concentration over time for strains 131 and 92, grown on ammonium, when cultures were grown with air and HEPES or PIPES. With buffers, the $\mathrm{pH}$ decrease of the medium was limited to less than one $\mathrm{pH}$ unit in all experiments. Both strains

Table 1 Comparison of average specific growth rate during exponential phase, final biomass concentration, growth yield relative to nitrogen as well as biodiesel potential and content of strain 131 grown on nitrate, ammonium, or urea

\begin{tabular}{llllllll}
\hline $\begin{array}{l}\text { Nitrogen } \\
\text { source }\end{array}$ & Sparge & pH buffer & $\begin{array}{l}\text { Specific growth } \\
\text { rate }\left(\text { day }^{-1}\right)\end{array}$ & $\begin{array}{l}\text { Final DCW } \\
\left(\mathrm{g} \mathrm{L} \mathrm{L}^{-1}\right)\end{array}$ & $\begin{array}{l}\text { Yield [g-biomass } \\
\left.(\mathrm{g}-\text { nitrogen })^{-1}\right]^{\mathrm{a}}\end{array}$ & $\begin{array}{l}\text { Biodiesel potential } \\
(\% w / w)^{\mathrm{b}}\end{array}$ & $\begin{array}{l}\text { Biodiesel content } \\
(\mathrm{g} \mathrm{L})^{\mathrm{c}}\end{array}$ \\
\hline $\mathrm{Urea}$ & $5 \% \mathrm{CO}_{2}$ & - & $1.02(1.01-1.05)$ & $1.89(1.85-1.96)$ & $42.1(40.0-44.8)$ & $30.2(29.1-31.0)$ & $0.58(0.55-0.61)$ \\
$\mathrm{NO}_{3}{ }^{-}$ & $5 \% \mathrm{CO}_{2}$ & - & $1.12(1.05-1.17)$ & $2.41(2.36-2.44)$ & $55.0(52.4-56.7)$ & $25.6(24.5-26.6)$ & $0.62(0.58-0.65)$ \\
$\mathrm{NO}_{3}{ }^{-}$ & Air & - & $0.45(0.42-0.46)$ & $1.23(0.96-1.39)$ & $25.8(21.4-26.48)$ & $33.4(26.7-37.3)$ & $0.42(0.26-0.52)$ \\
$\mathrm{NH}_{4}{ }^{+}$ & $5 \% \mathrm{CO}_{2}$ & - & $0.90(0.86-0.95)$ & $0.34(0.29-0.42)$ & $11.4(10.7-12.6)$ & $8.9(8.0-10.4)$ & $0.03(0.02-0.04)$ \\
$\mathrm{NH}_{4}{ }^{+}$ & Air & - & $0.55(0.50-0.58)$ & $0.26(0.24-0.28)$ & $8.8(8.5-9.1)$ & $8.2(6.6-11.0)$ & $0.02(0.02-0.03)$ \\
$\mathrm{NH}_{4}{ }^{+}$ & Air & HEPES & $0.22(0.21-0.24)$ & $0.70(0.56-0.82)$ & $17.3(13.9-20.7)$ & $18.4(19.1-17.7)$ & $0.14(0.13-0.15)$ \\
$\mathrm{NH}_{4}^{+}$ & Air & PIPES & $0.26(0.25-0.27)$ & $0.58(0.47-0.65)$ & $14.3(11.4-16.5)$ & $12.4(9.1-17.1)$ & $0.08(0.04-0.11)$ \\
$\mathrm{NH}_{4}{ }^{+}$ & $5 \% \mathrm{CO}_{2}$ & PIPES & $1.04(1.01-1.09)$ & $1.64(1.62-1.65)$ & $42.8(42.4-43.3)$ & $19.2(18.6-19.5)$ & $0.31(0.31-0.32)$ \\
$\mathrm{NH}_{4}^{+}$ & $5 \% \mathrm{CO}_{2}$ & PIPES/KOH & $1.18(1.16-1.19)$ & $2.09(2.00-2.17)$ & $45.3(44.3-46.5)$ & $19.0(18.8-19.2)$ & $0.40(0.39-0.42)$ \\
$\mathrm{NH}_{4}{ }^{+}$ & $5 \% \mathrm{CO}_{2}$ & Controlled 1 & $1.04(0.94-1.14)$ & $2.25(2.13-2.37)$ & $50.7(49.2-52.2)$ & $19.5(18.3-20.6)$ & $0.44(0.39-0.48)$ \\
$\mathrm{NH}_{4}^{+}$ & $5 \% \mathrm{CO}_{2}$ & Controlled 2 & $1.05(1.02-1.08)$ & $1.87(1.89-1.84)$ & $47.9(47.6-48.2)$ & $19.0(18.6-19.5)$ & $0.36(0.35-0.36)$ \\
\hline
\end{tabular}

Values are reported as the mean with the range (min-max) of the triplicates given in parentheses with the exception of the $\mathrm{pH}$ controlled treatment values, which are reported as the mean and range of duplicate treatments

${ }^{\text {a }}$ Calculated using Eq. 1

${ }^{\mathrm{b}}$ Calculated using Eq. 2

${ }^{\mathrm{c}}$ Calculated using Eq. 3 
Table 2 Comparison of average specific growth rate during exponential phase, final biomass concentration, growth yield relative to nitrogen as well as biodiesel potential and content of strain 92 grown on nitrate, ammonium, or urea

\begin{tabular}{llllllll}
\hline $\begin{array}{l}\text { Nitrogen } \\
\text { source }\end{array}$ & Sparge & pH buffer & $\begin{array}{l}\text { Specific growth } \\
\text { rate }\left(\text { day }^{-1}\right)\end{array}$ & $\begin{array}{l}\text { Final DCW } \\
\left(\mathrm{g} \mathrm{L}^{-1}\right)\end{array}$ & $\begin{array}{l}\text { Yield [g-biomass } \\
\left.(\mathrm{g}-\text { nitrogen })^{-1}\right]^{\mathrm{a}}\end{array}$ & $\begin{array}{l}\text { Biodiesel potential } \\
(\% / w)^{\mathrm{b}}\end{array}$ & $\begin{array}{l}\text { Biodiesel content } \\
(\mathrm{g} \mathrm{L})^{-1}\end{array}$ \\
\hline Urea & $5 \% \mathrm{CO}_{2}$ & - & $1.27(1.24-1.34)$ & $1.30(1.02-1.62)$ & $29.9(22.0-36.6)$ & $33.9(30.9-36.50$ & $0.45(0.32-0.59)$ \\
$\mathrm{NO}_{3}{ }^{-}$ & $5 \% \mathrm{CO}_{2}$ & - & $1.09(1.01-1.14)$ & $1.89(1.86-1.96)$ & $42.9(42.2-44.7)$ & $38.4(37.0-40.6)$ & $0.72(0.70-0.75)$ \\
$\mathrm{NO}_{3}{ }^{-}$ & Air & - & $0.43(0.38-0.47)$ & $1.13(0.91-1.32)$ & $24.4(19.8-28.2)$ & $24.1(22.7-26.1)$ & $0.27(0.22-0.35)$ \\
$\mathrm{NH}_{4}{ }^{+}$ & $5 \% \mathrm{CO}_{2}$ & - & $1.13(1.13-1.14)$ & $0.51(0.50-0.52)$ & $15.2(15.1-15.4)$ & $23.80(14.1-35.5)$ & $0.12(0.07-0.18)$ \\
$\mathrm{NH}_{4}{ }^{+}$ & Air & - & $0.49(0.48-0.50)$ & $0.37(0.35-0.39)$ & $12.9(12.3-13.6)$ & $14.1(13.9-14.5)$ & $0.04(0.04-0.04)$ \\
$\mathrm{NH}_{4}{ }^{+}$ & Air & HEPES & $0.45(0.44-0.46)$ & $0.93(0.90-0.96)$ & $22.5(21.0-24.1)$ & $21.9(19.2-24.6)$ & $0.20(0.18-0.24)$ \\
$\mathrm{NH}_{4}{ }^{+}$ & Air & PIPES & $0.46(0.44-0.47)$ & $0.88(0.82-0.90)$ & $19.1(17.2-20.4)$ & $13.8(13.3-14.6)$ & $0.12(0.11-0.14)$ \\
$\mathrm{NH}_{4}{ }^{+}$ & $5 \% \mathrm{CO}_{2}$ & PIPES & $1.31(1.26-1.30)$ & $1.70(1.67-1.73)$ & $42.3(38.5-45.6)$ & $35.4(32.4-38.4)$ & $0.59(0.65-0.54)$ \\
$\mathrm{NH}_{4}{ }^{+}$ & $5 \% \mathrm{CO}_{2}$ & PIPES/KOH & $1.58(1.56-1.61)$ & $1.26(1.08-1.52)$ & $29.0(25.5-33.8)$ & $33.8(31.1-38.5)$ & $0.42(0.37-0.48)$ \\
$\mathrm{NH}_{4}{ }^{+}$ & $5 \% \mathrm{CO}_{2}$ & Controlled 1 & $1.43(1.42-1.43)$ & $1.47(1.41-1.52)$ & $36.4(34.4-38.3)$ & $28.5(26.0-30.9)$ & $0.42(0.37-0.47)$ \\
$\mathrm{NH}_{4}{ }^{+}$ & $5 \% \mathrm{CO}_{2}$ & Controlled 2 & $1.41(1.34-1.47)$ & $1.71(1.66-1.76)$ & $41.4(40.4-42.4)$ & $31.8(29.5-34.1)$ & $0.54(0.52-0.57)$ \\
\hline
\end{tabular}

Values are reported as the mean with the range (min-max) of the triplicates given in parentheses with the exception of the $\mathrm{pH}$ controlled treatment values, which are reported as the mean and range of duplicate treatments

${ }^{\text {a }}$ Calculated using Eq. 1

${ }^{\mathrm{b}}$ Calculated using Eq. 2

${ }^{\mathrm{c}}$ Calculated using Eq. 3

exhibited better growth over 26 days when the medium was buffered with $8 \mathrm{mM}$ HEPES or PIPES and aerated with ambient air compared to growth in unbuffered medium. Both strain 131 and 92 showed similar growth behaviors between HEPES and PIPES buffer and likely became carbon limited after 4 days based on the change in growth rates. Cultures of both strains were monitored for 26 days to ensure stationary phase was reached. Ammonium concentrations remained low, below the limit of quantification for the Nessler assay $(0.1 \mathrm{mM})$, until the time of harvesting, except for strain 92 buffered with HEPES, which removed ammonium below the detection limit by day 16. Both strains utilized ammonium at a slower rate than nitrate when sparged with ambient air (cf. Fig. 3) and reached lower final DCWs. While the biodiesel potential and content of the two strains improved compared to experiments without buffers, the biodiesel potential and content were still significantly lower compared to cultures grown on nitrate or urea.

Growth on ammonium with synthetic buffers and $5 \% \mathrm{CO}_{2}$ aeration

Figure 4 also shows ( $a, b)$ nitrogen concentrations (millimolar $\mathrm{N}),(\mathrm{c}, \mathrm{d}) \mathrm{pH}$ of the medium, and (e, f) cell concentration over time for strains 131 and 92 when cultures were grown on ammonium with $5 \% \mathrm{CO}_{2}$ and PIPES or $5 \% \mathrm{CO}_{2}$ and PIPES with a $2 \mathrm{mM} \mathrm{KOH}$ injection at 4.7 days. PIPES was utilized in experiments with $5 \% \mathrm{CO}_{2}$ due to the similarity of the PIPES $\mathrm{pKa}$ with the $\mathrm{pH}$ of the unbuffered medium as shown in experiments with nitrate and urea. Figure 4 demonstrates that growth on ammonium with $5 \% \mathrm{CO}_{2}$ buffered with PIPES allowed for rapid ammonium utilization by both strains; ammonium was removed from the medium after 6 and 5 days, respectively, for strains 131 and 92 . Overall, both strains had higher final cell concentrations compared to cultures grown with ammonium in ambient air (with synthetic buffer) or in unbuffered medium. The $\mathrm{pH}$ for both strains was initially at pH 6.6 and decreased to a final $\mathrm{pH}$ of 6.1, due to acidification of the medium during ammonium uptake. To assess what would occur if the $\mathrm{pH}$ remained higher, $2 \mathrm{mM} \mathrm{KOH}$ (final concentration) was added when the $\mathrm{pH}$ had decreased below $\mathrm{pH} 6.4$ to increase the $\mathrm{pH}$ to 6.8 . Figure 4 shows the $2 \mathrm{mM}$ $\mathrm{KOH} \mathrm{pH}$ adjustment had little effect on growth or ammonium utilization for either strain, indicating that a $\mathrm{pH}$ decrease to approximately 6 had little effect on the growth and ammonium consumption of either species.

Both strains 131 (Table 1) and 92 (Table 2) when grown on ammonium, PIPES buffer, $5 \% \mathrm{CO}_{2}$ aeration, and with or without the addition of $2 \mathrm{mM} \mathrm{KOH}$ showed growth rates and final DCWs similar to growth on urea or nitrate with $5 \% \mathrm{CO}_{2}$. For strain 92, the biodiesel potential with ammonium was comparable to growth on nitrate and urea. However, strain 131 when grown on ammonium had a lower biodiesel potential and content than the other nitrogen sources indicating differences in the two species' response to growth on different nitrogen sources.

Growth on ammonium using chemical $\mathrm{pH}$ control

Since synthetic buffers are not an economic solution for $\mathrm{pH}$ control in large-scale operations, strains 131 and 92 were 
Fig. 3 Mean and range (error bars) of $\mathbf{a}, \mathbf{b}$ medium nitrogen concentration ( $\mathrm{mM}$ $\mathrm{N}), \mathbf{c}, \mathbf{d ~ p H}$, and $\mathbf{e}, \mathbf{f}$ live cell density for triplicate cultures of a, c, e Scenedesmus sp. 131 and b, d, f Monoraphidium sp. 92 grown using an ambient air sparge using nitrate (filled square) or ammonium (triangle) as the nitrogen source

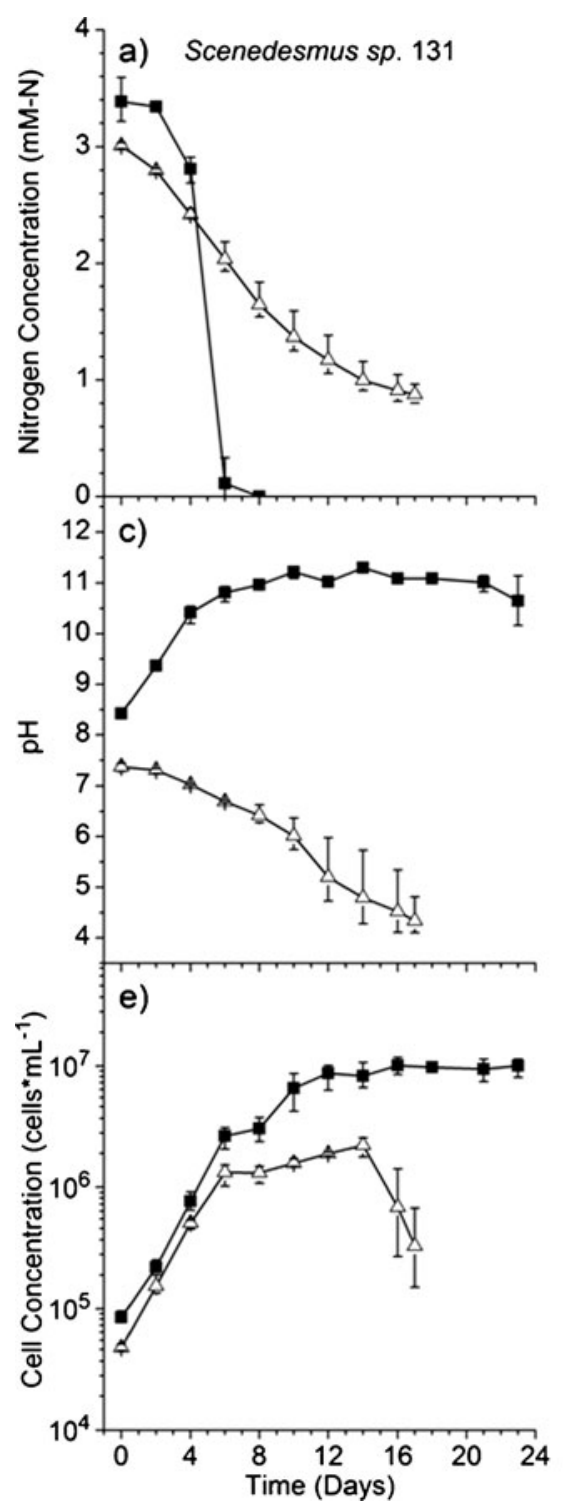

grown on ammonium with a $5 \% \mathrm{CO}_{2}$ gas sparge while maintaining a near-constant $\mathrm{pH}$ through addition of $0.1 \mathrm{M}$ $\mathrm{KOH}$. Figure 5 shows $(\mathrm{a}, \mathrm{b})$ nitrogen concentrations (mM$\mathrm{N}),(\mathrm{c}, \mathrm{d}) \mathrm{pH}$ of the medium, and (e, f) cell concentration over time for strains 131 and 92 grown on ammonium using $\mathrm{pH}$ control. These cultures were grown in duplicate in two separate experiments. The $\mathrm{pH}$ of the medium prior to inoculation was pH 6.2 and was increased in a stepwise manner to a final $\mathrm{pH}$ of 6.55 over the first 2 days and remained stable for the duration of the experiment $(6.55 \pm 0.1)$. The $\mathrm{pH}$ was increased incrementally to allow the bicarbonate equilibrium to shift during algal growth to aid in the $\mathrm{pH}$ increase and to reduce the amount of $\mathrm{KOH}$ required to achieve the final $\mathrm{pH}$. After 2 days, the $\mathrm{pH}$ was set to $6.55 \pm 0.1$ because it was the highest $\mathrm{pH}$ allowable with $5 \% \mathrm{CO}_{2}$ aeration without the addition of $0.1 \mathrm{M} \mathrm{KOH}$ significantly changing the

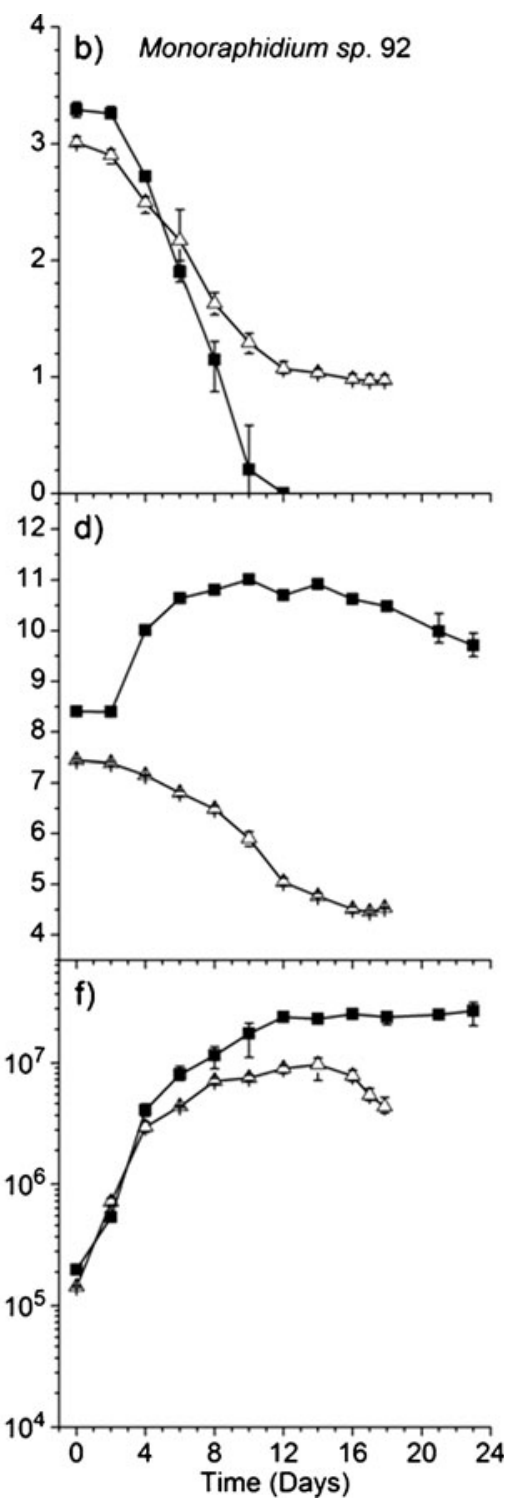

volume of the reactors, and thus allowed for better comparison to experiments conducted with nitrate and urea. Higher concentrations of $\mathrm{KOH}$ could have been used to reduce necessary volumes, but inhibitory effects of high, localized concentrations during the dropwise, automated addition of $\mathrm{KOH}$ were a concern.

Both strains consumed the measurable ammonium by day 6 and reached stationary phase by day 9 (Fig. 5). Strain 131 exhibited a longer lag phase in one of the reactors during run 1 , which produced the large error bars in Fig. 5a, e. The biodiesel potential, final DCW, and specific growth rate for strains 131 and 92 were statistically the same as for growth on ammonium with PIPES and $5 \% \mathrm{CO}_{2}$. The time required for removal of nitrogen when grown on $5 \% \mathrm{CO}_{2}$ with all three nitrogen sources (nitrate, urea, and buffered ammonium) was 
Fig. 4 Mean and range (error bars) of $\mathbf{a}, \mathbf{b}$ medium nitrogen concentration (mM$\mathrm{N}), \mathbf{c}, \mathbf{d ~ p H}$, and $\mathbf{e}, \mathbf{f}$ cell density for triplicate cultures of $\mathbf{a}, \mathbf{c}, \mathbf{e}$ Scenedesmus sp. 131 and $\mathbf{b}, \mathbf{d}, \mathbf{f}$ Monoraphidium sp. 92 with ammonium as the nitrogen source. Media were sparged with air and buffered with $8 \mathrm{mM}$ HEPES (filled circle), air and $8 \mathrm{mM}$ PIPES (circle), $5 \%$ $\mathrm{CO}_{2}$ and $8 \mathrm{mM}$ PIPES (filled square), or $5 \% \mathrm{CO}_{2}$ and $8 \mathrm{mM}$ PIPES with a $2-\mathrm{mM} \mathrm{KOH}$ injection (square)
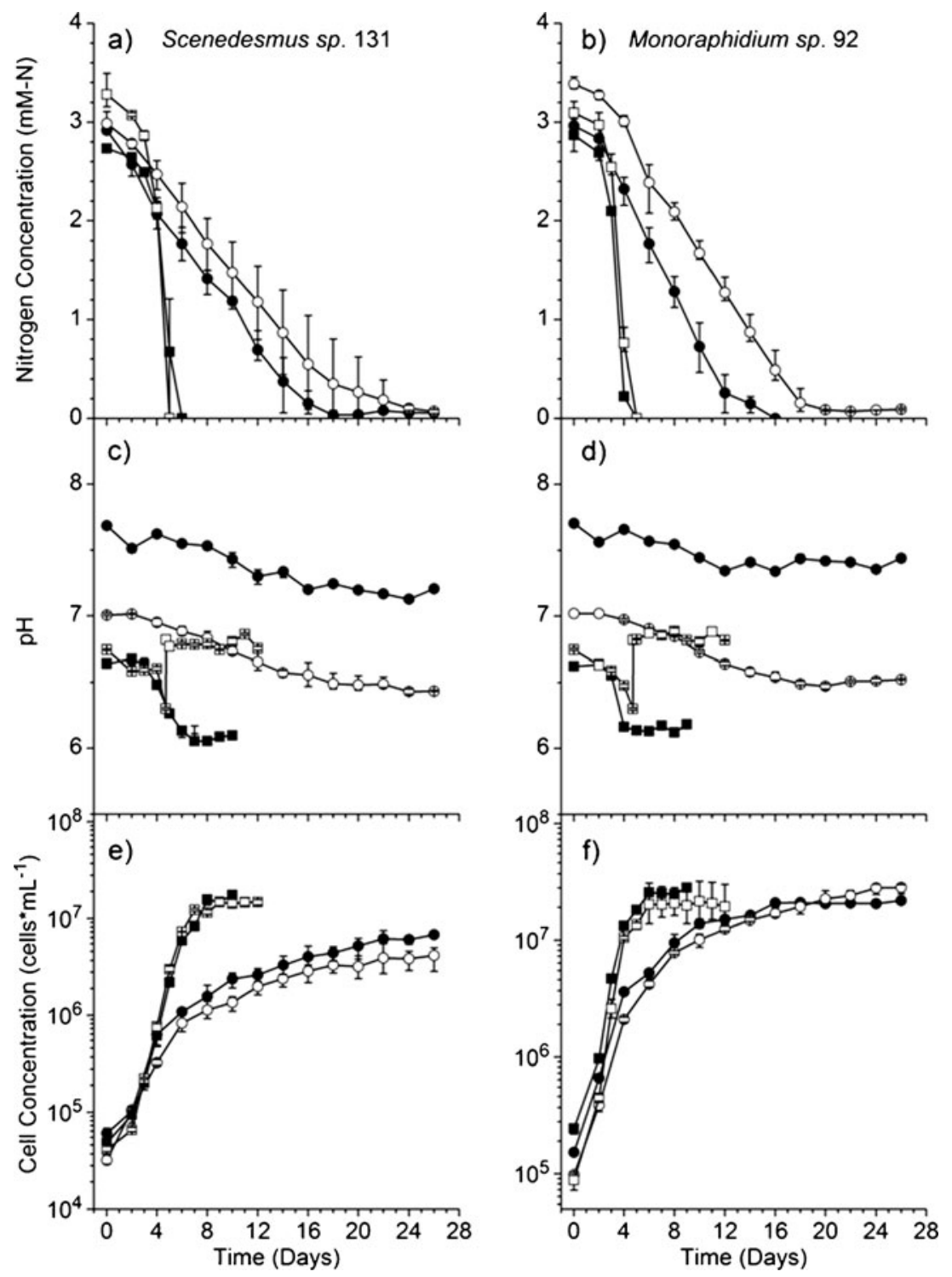

between 5 and 6 days for both strains and resulted in a high $Y_{\mathrm{X} / \mathrm{N}}$ in comparison to growth with ambient aeration. This was expected as the $5 \% \mathrm{CO}_{2}$ concentration provided an environment where faster algal growth supported faster nitrogen removal.

Strain 131 showed a higher biodiesel potential and biodiesel content for growth on nitrate and urea compared to ammonium (Table 1), whereas strain 92 aerated with $5 \% \mathrm{CO}_{2}$, showed a biodiesel potential not statistically significantly different between all three nitrogen sources. A comparison of Tables 1 and 2 shows that the biodiesel content of strain 92 was less affected by the nitrogen source compared to strain 131. However, for both strains, the best nitrogen source for producing biodiesel was nitrate. Tables 1 and 2 provide further evidence that the nitrogen source and $\mathrm{CO}_{2}$ concentrations have significant impact on the biodiesel content and to a certain extent the viability of a given species for large scale biodiesel production.

\section{Discussion}

Observed effects of the $\mathrm{pH}$ decrease

Previous studies have shown high algal growth rates are possible in the presence of increased $\mathrm{CO}_{2}$ concentrations (Gardner et al. 2012; Giordano and Bowes 1997; Yun et al. 1997). The observed $\mathrm{pH}$ behavior for growth on urea was expected because the transport of this neutral molecule does not require the release of hydroxyl ions or protons to maintain cell neutrality (Fernández et al. 2004; Hodson and Thompson 1969). However, for strains 131 and 92 grown 
Fig. 5 Mean and range (error bars) of $\mathbf{a}, \mathbf{b}$ medium nitrogen concentration (mM$\mathrm{N}), \mathbf{c}, \mathbf{d ~ p H}$, and $\mathbf{e}, \mathbf{f}$ cell density for two separate experiments with duplicate cultures of $\mathbf{a}, \mathbf{c}, \mathbf{e}$ Scenedesmus sp. 131 and $\mathbf{b}, \mathbf{d}, \mathbf{f}$ Monoraphidium sp. 92 with ammonium as the nitrogen source and $\mathrm{pH}$ control, run 1 (filled square) and run 2 (circle)
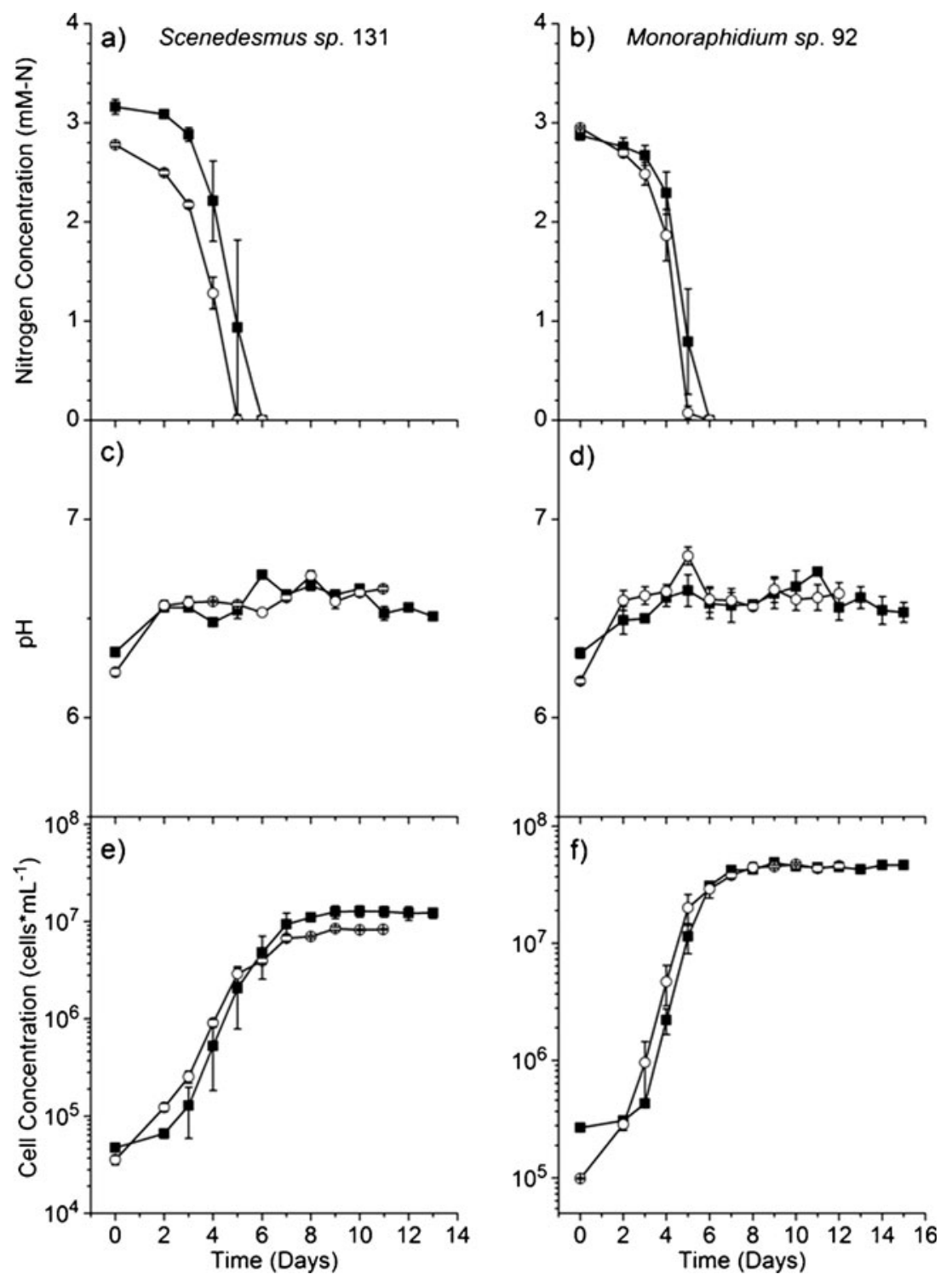

on ammonium, the $\mathrm{pH}$ showed a decrease in unbuffered media, which caused growth inhibition and apparent chlorophyll degradation. The reactors transitioned from a bright green to brown/yellow, and finally to white as the cell chlorophyll content decreased. The reason for this is unclear, but such behavior has been documented in algae and cyanobacteria (Dorling et al. 1997; Kallas and Castenholz 1982a). Researchers have demonstrated that the cytosolic $\mathrm{pH}$ of the cell remains constant in both prokaryotic and eukaryotic cells during a decrease in medium pH (Gehl and Colman 1985; Kallas and Castenholz 1982a). If this holds true for the strains tested here, a decrease in extracellular $\mathrm{pH}$ would not be the cause of chlorophyll degradation, thus it would be likely that chlorophyll degradation is a result of decreased cell viability. Rees (1989) suggested that at low $\mathrm{pH}$ values, algal strains will release ammonium into the medium during the dark cycle, while
Dorling et al. (1997) found that growth in continuous light did not have the same effect. It has also been suggested that low medium $\mathrm{pH}$ values created a tighter packing orientation of phospholipids in cell membranes due to increased protonation, which in turn reduced membrane permeability (Lavoie et al. 2012). This could explain why research has shown a decrease in solute transport and ammonium uptake at lower $\mathrm{pH}$ values (Kallas and Castenholz 1982b; McAuley et al. 1996). Kallas and Castenholz (1982b) also observed that Synechococcus cells which were not adapted to growth at low $\mathrm{pH}$ demonstrated no net DNA synthesis at low $\mathrm{pH}$ values. Therefore, when the strains were grown at high ammonium concentrations in unbuffered or low alkalinity medium, the large shift in $\mathrm{pH}$ likely prevented the cultures from being highly productive. Previous research associated with growth on ammonium often did not take into account changes in $\mathrm{pH}$ because it was not monitored or controlled, 
and therefore was not considered as a factor for reduced DCW (Chen et al. 2011; Li et al. 2008).

\section{Effects of growing strains with ambient aeration}

Previous studies with different algae have shown that unbuffered growth on nitrate with ambient air allowed the pH to increase (Chen and Durbin 1994; Gardner et al. 2012; Guckert and Cooksey 1990; Voltolina et al. 1999). This likely occurs due to $\mathrm{CO}_{2}$ depletion, unless cell density is very low or the rate of $\mathrm{CO}_{2}$ ingassing is high, but can also result from the extrusion of $\mathrm{OH}^{-}$ions for internal $\mathrm{pH}$ maintenance. Here, both strains showed similar $\mathrm{pH}$ increases when grown on nitrate and ambient air, but reached lower cell concentrations and DCWs in comparison to $5 \% \mathrm{CO}_{2}$. These decreases in DCW during ambient air cultivation are attributed to the increase in $\mathrm{pH}$ and/or carbon limitation. The decrease in DCW for both strains affected the biodiesel content, which is more important than assessing only the biodiesel potential of the cell. Therefore, when strain 131 was grown on nitrate with air, the biodiesel potential of the cells increased similar to other algae previously reported by Gardner et al. (2011); however, due to the decrease in DCW, the overall biodiesel content decreased. This suggests that utilizing conditions promoting faster growth, but slightly lower biodiesel potential may provide better overall biodiesel productivity.

In contrast to nitrate, ammonium decreased the rate of growth and nitrogen uptake (Fig. 3). Shifts in the $\mathrm{pH}$ of the medium were expected due to the low buffering capacity of BBM and the high concentrations of either nitrate or ammonium whose uptake causes a flux of hydroxyl ions or protons, respectively, back into the medium (Fuggi et al. 1981; Goldman and Brewer 1980). The $\mathrm{pH}$ of the medium is also affected by the alkalinity of the system. At the initial $\mathrm{pH}$ values investigated here, bicarbonate $\left(\mathrm{HCO}_{3}{ }^{-}\right)$was the predominant form of inorganic carbon available for growth. Uptake of $\mathrm{CO}_{2}$ results in the alkalization of the medium due to the release of hydroxyl ions during the re-speciation from $\mathrm{HCO}_{3}{ }^{-}$to $\mathrm{CO}_{2}$ (Shiraiwa et al. 1993). The combined effect of nitrate uptake and DIC utilization caused the $\mathrm{pH}$ to increase to $\mathrm{pH} 11.3$ and $\mathrm{pH} 11.0$ for strains 131 and 92, respectively (Fig. 3). However, when the strains were grown on ammonium, the concentration of protons released during ammonium utilization was greater than the release of hydroxyl ions from DIC uptake, which resulted in a net decrease in the $\mathrm{pH}$ of the system to below $\mathrm{pH}$ 5. Utilizing ambient air reduced the growth rate and, as a result, the rate at which the $\mathrm{pH}$ in the system decreased, which in turn allowed for a better assessment of the limiting $\mathrm{pH}$. Comparison of Figs. 1 and 3 shows that cell concentrations began to decrease once the $\mathrm{pH}$ of the medium was below $\mathrm{pH}$ 5. These results are comparable to a recent study by Xin et al. (2010) describing algal growth in unbuffered medium with ammonium or nitrate in a carbon-limited environment, which reported that algal growth became inhibited in the presence of ammonium once the $\mathrm{pH}$ decreased below 5 . As a result, ammonium was never fully utilized in these cultures resulting in lower cell concentrations compared to growth on nitrate.

Improving growth on ammonium with synthetic buffers

The abundance of ammonium in wastewater and its ability to inhibit utilization of other nitrogen sources in a mixed nitrogen medium dictate the importance for studying methods to improve ammonium utilization, especially if algal growth on ammonium is to be coupled with biodiesel production. Research has documented high ammonium removal rates from wastewater using algae (Aslan and Kapdan 2006; Nunez et al. 2001; Voltolina et al. 1999; Xin et al. 2010). However, few studies have attempted to determine a biodiesel potential with ammonium as the nitrogen source. Recently, lipid accumulation for algae growing on ammonium in comparison to nitrate was reported by Li et al. (2008), but the paper did not take into account the decrease in the medium $\mathrm{pH}$, which can inhibit cell growth and is a potential cause for decreased cell yield and biodiesel content. Additionally, previous papers on algal ammonium removal did not consider the effects of $\mathrm{pH}$ and $\mathrm{CO}_{2}$ concentration on the rates of ammonium removal (Garcia et al. 2000; Voltolina et al. 1999). When cultures were grown on ammonium in the presence of $\mathrm{CO}_{2}$ or air, the $\mathrm{pH}$ decreased rapidly (Figs. 1 and 3), causing the strains to become inhibited and the chlorophyll to degrade.

To assess the ability of strains 131 and 92 to grow on ammonium with ambient aeration, $8 \mathrm{mM}$ of the synthetic buffer PIPES (pKa 6.8) or HEPES (pKa 7.5) was added to the media. Results show that the difference in $\mathrm{pH}$ during growth of both strains on ambient air with HEPES (mean $\mathrm{pH}$ 7.37-strain 131 and 7.47-strain 92) or PIPES (mean pH 6.68 - strain 131 and 6.70 - strain 92) had little effect on the maximum specific growth rate or the cell concentration at which the medium became carbon limited. However, the decrease in $\mathrm{pH}$ from HEPES to PIPES (Fig. 4) reduced the availability of DIC. The equilibrium DIC concentration of the medium is primarily influenced by the $\mathrm{pH}$ (Benjamin 2010), and DIC availability is based on the carbon flux into the medium, which is dependent upon the difference in the actual DIC concentration compared to the equilibrium concentration. The decrease in $\mathrm{pH}$ between experiments with HEPES and PIPES using ambient aeration could decrease the DIC availability in the PIPES-buffered medium, which could account for the decrease in biodiesel potential of both strains in the lower $\mathrm{pH}$ PIPES-buffered systems.

Previous research has discussed carbon limitation and PEPC having a higher affinity for carbon than RUBISCO. 
Further, PEPC has been shown to be upregulated in the presence of ammonium (Elrifi et al. 1988; Guy et al. 1989; Schuller et al. 1990; Turpin and Bruce 1990). The upregulation of PEPC shifts the primary metabolic pathways and decreases the amount of carbon available for photosynthesis and fatty acid production. Therefore, it is possible that a decrease in the DIC availability would decrease the biofuel potential of a strain growing on ammonium by reducing the amount of carbon being converted to fatty acids and triacylglycerol (TAG). This observation provides support to the hypothesis that optimized growth on ammonium requires increased DIC levels greater than what is obtainable from growth on air.

In addition, Tables 1 and 2 show both strains exhibited a lower biodiesel potential when grown on air and ammonium in synthetically buffered medium when compared to nitrate and air. This may be due to the lack of two key parameters shown to increase lipid content: (1) high pH-induced TAG accumulation observed when algae are grown on nitrate and aerated with ambient air, similar to previous reports (Gardner et al. 2011) and (2) nitrogen depletion, which is known to cause cell cycle inhibition and allows for an increase in lipid content (Rodolfi et al. 2009; Widjaja et al. 2009).

Previous research has shown that carbon limitation can decrease algal growth on ammonium through two mechanisms, (1) reduced growth rates with lower DCWs due to preferential carbon utilization in anaplerotic reactions (Amory et al. 1991; Elrifi et al. 1988; Norici and Giordano 2002; Vanlerberghe et al. 1990) and (2) decreased ammonium uptake (Di Martino Rigano et al. 1986; Turpin et al. 1991). Thus, for efficient ammonium removal, inorganic carbon must be abundant. When strains 131 and 92 were grown on ammonium with $5 \% \mathrm{CO}_{2}$, buffered using PIPES, both strains showed a significant improvement in the utilization of ammonium. The results, however, also show that strain 131 had a lower biodiesel potential when grown on buffered ammonium compared to nitrate (Table 2), while strain 92 had comparable biodiesel potential results for all nitrogen sources (Table 1). Research has shown that algal strains can have different lipid contents depending on the nitrogen source which may be attributed to an increase in other cellular components such as proteins, and the optimal nitrogen source is strain dependent (Lourenco et al. 2002; Piorreck et al. 1984). However, additional experimentation is needed to address that hypothesis.

Growth on ammonium using $\mathrm{pH}$ control for scalability

To further evaluate the influence of $\mathrm{pH}$ in an attempt to provide a link to scalable systems, both strains were grown on $5 \% \mathrm{CO}_{2}$ and were $\mathrm{pH}$ controlled. $\mathrm{pH}$ control in large-scale applications is challenging. When growing algae on nitrate as the nitrogen source, $\mathrm{pH}$ can be controlled by increasing the $\mathrm{CO}_{2}$ concentration of the sparging source or by utilizing a secondary sparging system containing pure $\mathrm{CO}_{2}$. However, growing algae with ammonium as the nitrogen source has two different complications, (1) the inability to maintain growth due to the significant decrease in $\mathrm{pH}$ and (2) the potential decrease in biodiesel potential as previously discussed for strain 131 (Table 1). The effects of $\mathrm{pH}$ inhibition can be minimized through $\mathrm{pH}$ control by base addition and $\mathrm{CO}_{2}$ limitation can be eliminated by increasing concentrations of $\mathrm{CO}_{2}$. The results show that the biodiesel potential and final DCW, for strains 131 and 92 grown with $\mathrm{KOH}-$ based $\mathrm{pH}$ control, were comparable to growth on ammonium with PIPES and $5 \% \mathrm{CO}_{2}$, and the overall algal growth rate was comparable to growth on $5 \% \mathrm{CO}_{2}$ in all other conditions. This suggests that growth with active $\mathrm{pH}$ control may be a viable method for biofuel production using ammonium as a nitrogen source.

Analysis of culture conditions for optimal nitrogen removal

Culture conditions had a significant impact on the strains' abilities to remove nitrogen from the media. The main factor that affected growth, and therefore nitrogen uptake, was DIC availability. As observed by others (Amory et al. 1991; Di Martino Rigano et al. 1986), high concentrations of $\mathrm{CO}_{2}(5 \%)$ allowed the algae to more efficiently remove nitrogen from the medium. When the strains were grown on ammonium with air, compared to nitrate with air, the overall nitrogen removal rate for both strains was decreased. This can be explained with the increased carbon requirements for anaplerotic reactions for growth on ammonium over nitrate (Elrifi et al. 1988) and the decrease in $\mathrm{pH}$, which decreased the DIC availability. The decrease in $\mathrm{pH}$ associated with growth on ammonium appeared to be more detrimental than the $\mathrm{pH}$ increase associated with growth on nitrate.

Overall, Tables 1 and 2 demonstrate that increased $\mathrm{CO}_{2}$ concentrations resulted in higher algal biomass growth. Growth on $5 \% \mathrm{CO}_{2}$ resulted in the greatest yields, which indicates that the strains grown on air were likely DIC limited. Tables 1 and 2 also show that among these conditions, growth on nitrate with $5 \% \mathrm{CO}_{2}$ and growth on ammonium with $\mathrm{pH}$ control (via synthetic buffers or $\mathrm{pH}$ controllers) provided the highest cell yields. $Y_{\mathrm{X} / \mathrm{N}}$ values for growth on air with ammonium or nitrate were lower than for growth on $5 \% \mathrm{CO}_{2}$. Specifically, the yield for growth on nitrate with air was approximately half that of the yield for growth on nitrate with $5 \% \mathrm{CO}_{2}$. Growth on buffered ammonium with air gave lower yields than growth on nitrate with air. For both strains, yields were variable depending on the experimental conditions, most likely due to variations in DIC availability and possible $\mathrm{pH}$ inhibition for growth, but 
are within the range of previously reported yields for microalgae (Li et al. 2008).

Annual biodiesel productivity

To assess the overall annual biodiesel productivity (liters per hectare per year) for these strains, the data were extrapolated using four assumptions: (1) Cultures grown on $5 \% \mathrm{CO}_{2}$ had a 2.5 -week growth to harvest period (batch time), (2) cultures grown on air had a 3.5-week batch time due to the slower growth rate, (3) the density of FAME is $0.88 \mathrm{~kg}$ FAME (liter FAME) ${ }^{-1}$, and (4) algal growth ponds are $0.3 \mathrm{~m}$ deep, providing a total culture volume of $3 \times 10^{6} \mathrm{~L} \mathrm{ha}^{-1}$. These calculations were completed using Eq. 4, and the results are reported in Table 3.

Annual biodiesel productivity

$$
=\frac{\text { biodiesel content }}{\text { FAME density }} \times \frac{\text { culture volume }}{\text { area } \times \text { batch time }}
$$

Table 3 shows that sparging with $5 \% \mathrm{CO}_{2}$ compared to air increased the calculated annual biodiesel productivity. This is partially due to the shorter batch times necessary for $5 \% \mathrm{CO}_{2}$ sparged cultures. Table 3 also shows that even though growth on nitrate with $5 \% \mathrm{CO}_{2}$ could provide the greatest annual biodiesel production for both strains, growth on urea and growth on ammonium using $\mathrm{pH}$ control and $5 \% \mathrm{CO}_{2}$ could achieve biodiesel productivities on the same order of magnitude as nitrate and within the range previously reported (Chisti 2007; Rodolfi et al. 2009).

In conclusion, Scenedesmus sp. 131 and Monoraphidium sp. 92 were shown to effectively uptake nitrogen from a variety of sources. Further, it was shown that the main requirement for efficient nitrogen removal was an increased availability of dissolved inorganic carbon (DIC and a $\mathrm{pH}$ between 6 and 8). Specifically:

- Strains 131 and 92 grew on ammonium, but the $\mathrm{pH}$ of the medium must be maintained between 6.0 and 7.5 for robust growth using synthetic buffers (demonstrated with PIPES and HEPES) or $\mathrm{pH}$ controllers.

- Nitrogen removal was increased with increased $\mathrm{CO}_{2}$ addition. The increased availability of DIC in $5 \%$ $\mathrm{CO}_{2}$ sparged systems allowed for increased growth rates and nitrogen uptake, regardless of the nitrogen source.

- Strains grown with ammonium in PIPES buffer with $5 \% \mathrm{CO}_{2}$ exhibited nitrogen removal rates greater than when grown on air and were equivalent to growth on nitrate or urea with $5 \% \mathrm{CO}_{2}$.

- The growth rates of strains 131 and 92 on ammonium with $\mathrm{pH}$ control and $5 \% \mathrm{CO}_{2}$ were not statistically significantly different from growth on $5 \% \mathrm{CO}_{2}$ with nitrate or urea.

- Strain 131 had a lower biodiesel potential when grown on ammonium compared to growth on nitrate or urea with $5 \% \mathrm{CO}_{2}$. The biodiesel potential of strain 92 , in the presence of $5 \% \mathrm{CO}_{2}$, was less affected by the nitrogen source.

- A $5 \% \mathrm{CO}_{2}$ sparge increased the biodiesel content for both strains.

This study demonstrates that these strains can grow efficiently on ammonium as a sole nitrogen source, but that additional inorganic carbon (e.g., through a $5 \%$ $\mathrm{CO}_{2}$ sparge) and $\mathrm{pH}$ control must be provided to achieve higher biomass concentrations, biodiesel content, and nitrogen removal rates.
Table 3 Estimated annual biodiesel productivity for strains 131 and 92

\begin{tabular}{lllll}
\hline $\begin{array}{l}\text { Nitrogen } \\
\text { source }\end{array}$ & Sparge & pH buffer & $\begin{array}{l}\text { Scenedesmus sp. 131 annual } \\
\text { biodiesel productivity } \\
\left(\mathrm{L} \mathrm{ha}^{-1} \text { year }^{-1}\right)^{\mathrm{a}}\end{array}$ & $\begin{array}{l}\text { Monoraphidium sp. 92 annual } \\
\text { biodiesel productivity } \\
\left(\mathrm{L} \mathrm{ha}^{-1} \text { year }^{-1}\right)^{\mathrm{a}}\end{array}$ \\
\hline $\mathrm{Urea}$ & $5 \% \mathrm{CO}_{2}$ & - & 41,000 & 31,700 \\
$\mathrm{NO}_{3}{ }^{-}$ & $5 \% \mathrm{CO}_{2}$ & - & 43,800 & 51,400 \\
$\mathrm{NO}_{3}{ }^{-}$ & Air & - & 21,200 & 13,800 \\
$\mathrm{NH}_{4}^{+}$ & $5 \% \mathrm{CO}_{2}$ & - & 2,200 & 8,600 \\
$\mathrm{NH}_{4}{ }^{+}$ & Air & - & 1,500 & 1,900 \\
$\mathrm{NH}_{4}^{+}$ & Air & HEPES & 7,000 & 10,400 \\
$\mathrm{NH}_{4}^{+}$ & Air & PIPES & 3,800 & 6,200 \\
$\mathrm{NH}_{4}^{+}$ & $5 \% \mathrm{CO}_{2}$ & PIPES & 22,300 & 42,200 \\
$\mathrm{NH}_{4}^{+}$ & $5 \% \mathrm{CO}_{2}$ & PIPES+KOH & 28,600 & 30,100 \\
$\mathrm{NH}_{4}^{+}$ & $5 \% \mathrm{CO}_{2}$ & Controlled 1 & 31,000 & 30,000 \\
$\mathrm{NH}_{4}^{+}$ & $5 \% \mathrm{CO}_{2}$ & Controlled 2 & 17,800 & 38,500 \\
\hline
\end{tabular}


Acknowledgments The authors would like to thank the Montana State University Algal Biofuels Group for intellectual support and Lauren Franco for 18S rRNA gene sequence interrogations of Scenedesmus sp. 131. Also of special note is the MSU Center for Biofilm Engineering for instrumental support. Funding was provided by the Montana State Board of Research and Commercialization Technology Grant 10-40 and the National Science Foundation under CHE-1230632.

\section{References}

Abeliovich A, Azov Y (1976) Toxicity of ammonia to algae in sewage oxidation ponds. Appl Environ Microb 31:801-806

Amory AM, Vanlerberghe GC, Turpin DH (1991) Demonstration of both a photosynthetic and a nonphotosynthetic $\mathrm{CO}_{2}$ requirement for $\mathrm{NH}_{4}{ }^{+}$assimilation in the green alga Selenastrum minutum. Plant Physiol 95:192-196

Andersen RA (ed) (2005) Algal culturing techniques. Academic Press, San Francisco

Aslan S, Kapdan IK (2006) Batch kinetics of nitrogen and phosphorus removal from synthetic wastewater by algae. Ecol Eng 28:64-70

Azov Y, Goldman JC (1982) Free ammonia inhibition of algal photosynthesis in intensive cultures. Appl Environ Microbiol 43:735-739

Benjamin MM (2010) Water chemistry. Waveland Press Inc., Long Grove, Reprint edn

Bischoff HW, Bold HC (1963) Phycological studies. IV. Some soil algae from enchanted rock and related algal species. University of Texas Publication, Austin

Bongers LHJ (1956) Aspects of nitrogen assimilation by cultures of green algae. Mededel Landbouwhoogesch Wageningen 56/15:1-52

Chen CY, Durbin EG (1994) Effects of $\mathrm{pH}$ on the growth and carbon uptake of marine phytoplankton. Mar Ecol Prog Ser 109:83-94

Chen M, Tang H, Ma H, Holland TC, Ng KYS, Salley SO (2011) Effect of nutrients on growth and lipid accumulation in the green algae Dunaliella tertiolecta. Bioresour Technol 102:1649-1655

Chisti Y (2007) Biodiesel from microalgae. Biotechnol Adv 25:294-306

Christenson L, Sims R (2011) Production and harvesting of microalgae for wastewater treatment, biofuels, and bioproducts. Biotechnol Adv 29:686-702

Clark S, Francis PS, Conlan XA, Barnett NW (2007) Determination of urea using high-performance liquid chromatography with fluorescence detection after automated derivatisation with Xanthydrol. J Chromatogr A 1161:207-213

de Boer K, Moheimani NR, Borowitzka MA, Bahri PA (2012) Extraction and conversion pathways for microalgae to biodiesel: a review focused on energy consumption. J Appl Phycol 24:1681-1698

Di Martino Rigano V, Vona V, Di Martino C, Rigano C (1986) Effect of darkness and $\mathrm{CO}_{2}$ starvation on $\mathrm{NH}_{4}{ }^{+}$and $\mathrm{NO}_{3}{ }^{-}$assimilation in the unicellular alga Cyanidium caldarium. Physiol Plant 68:34-38

Dorling M, McAuley PJ, Hodge H (1997) Effect of pH on growth and carbon metabolism of maltose-releasing Chlorella (Chlorophyta). Eur J Phycol 32:19-24

Dortch Q (1990) The interaction between ammonium and nitrate uptake in phytoplankton. Mar Ecol Prog Ser 61:183-201

Dvořáková-Hladká J (1971) A comparison of growth rate of algae as influenced by variation in nitrogen nutrition in Chlorella pyrenoidosa and Scenedesmus obliquus. Biol Plant 13:1-11

Elrifi IR, Holmes JJ, Weger HG, Mayo WP, Turpin DH (1988) RuBP limitation of photosynthetic carbon fixation during $\mathrm{NH}_{4}{ }^{+}$assimilation: interactions between photosynthesis, respiration, and ammonium assimilation in N-limited green algae. Plant Physiol $87: 395-401$
Fernández E, Galván A, Quesada A (2004) Nitrogen assimilation and its regulation. In: The molecular biology of chloroplasts and mitochondria in Chlamydomonas. Govindjee (ed), vol 7. Advances in photosynthesis and respiration. Springer, Dordrecht, pp. 637-659

Fuggi A, Di Martino Rigano V, Vona V, Rigano C (1981) Nitrate and ammonium assimilation in algal cell-suspensions and related $\mathrm{pH}$ variations in the external medium, monitored by electrodes. Plant Sci Lett 23:129-138

Garcia J, Mujeriego R, Hernandez-Marine M (2000) High rate algal pond operating strategies for urban wastewater nitrogen removal. J Appl Phycol 12:331-339

Gardner R, Cooksey K, Mus F, Macur R, Moll K, Eustance E, Carlson R, Gerlach R, Fields M, Peyton B (2012) Use of sodium bicarbonate to stimulate triacylglycerol accumulation in the chlorophyte Scenedesmus sp. and the diatom Phaeodactylum tricornutum. J Appl Phycol 24:1311-1320

Gardner R, Peters P, Peyton B, Cooksey K (2011) Medium pH and nitrate concentration effects on accumulation of triacylglycerol in two members of the Chlorophyta. J Appl Phycol 23:1005-1016

Gardner RD, Lohman E, Gerlach R, Cooksey KE, Peyton BM (2013) Comparison of $\mathrm{CO}_{2}$ and bicarbonate as inorganic carbon sources for triacylglycerol and starch accumulation in Chlamydomonas reinhardtii. Biotechnol Bioeng 110:87-96

Gehl KA, Colman B (1985) Effect of external $\mathrm{pH}$ on the internal $\mathrm{pH}$ of Chlorella saccharophila. Plant Physiol 77:917-921

Giordano M, Bowes G (1997) Gas exchange and C allocation in Dunaliella salina cells in response to the $\mathrm{N}$ source and $\mathrm{CO}_{2}$ concentration used for growth. Plant Physiol 115:1049-1056

Goldman JC, Brewer PG (1980) Effect of nitrogen source and growth rate on phytoplankton-mediated changes in alkalinity. Limnol Oceanogr 25:352-357

Griffiths M, van Hille R, Harrison S (2010) Selection of direct transesterification as the preferred method for assay of fatty acid content of microalgae. Lipids 45:1053-1060

Guckert JB, Cooksey KE (1990) Triglyceride accumulation and fattyacid profile changes in Chlorella (Chlorophyta) during high $\mathrm{pH}$ induced cell-cycle inhibition. J Phycol 26:72-79

Guy RD, Vanlerberghe GC, Turpin DH (1989) Significance of phosphoenolpyruvate carboxylase during ammonium assimilation: carbon isotope discrimination in photosynthesis and respiration by the N-limited green alga Selenastrum minutum. Plant Physiol $89: 1150-1157$

Hodson RC, Thompson JF (1969) Metabolism of urea by Chlorella vulgaris. Plant Physiol 44:691-696

Kallas T, Castenholz RW (1982a) Internal pH and ATP-ADP pools in the cyanobacterium Synechococcus sp. during exposure to growth-inhibiting low $\mathrm{pH}$. J Bacteriol 149:229-236

Kallas T, Castenholz RW (1982b) Rapid transient growth at low pH in the cyanobacterium Synechococcus sp. J Bacteriol 149:237-246

Lavoie M, Le Faucheur S, Boullemant A, Fortin C, Campbell PGC (2012) The influence of $\mathrm{pH}$ on algal cell membrane permeability and its implications for the uptake of lipophilic metal complexes. J Phycol 48:293-302

Li YQ, Horsman M, Wang B, Wu N, Lan CQ (2008) Effects of nitrogen sources on cell growth and lipid accumulation of green alga Neochloris oleoabundans. Appl Microbiol Biotech 81:629-636

Lourenco SO, Barbarino E, Mancini-Filho J, Schinke KP, Aidar E (2002) Effects of different nitrogen sources on the growth and biochemical profile of 10 marine microalgae in batch culture: an evaluation for aquaculture. Phycologia 41:158-168

Ludwig CA (1938) The availability of different forms of nitrogen to a green alga. Am J Bot 25:448-458

Lundquist T, Woertz I, Quinn NWT, Benemann JR (2010) A realistic technology and engineering assessment of algae biofuel production. Energy Biosciences Institute, Berkeley 
Marvan P, Komarek J, Comas A (1984) Weighting and scaling of features in numerical evaluation of coccal green algae Selenastraceae. Arch Hydrobiol Suppl 67:363-400

McAuley PJ, Dorling M, Hodge H (1996) Effect of maltose release on uptake and assimilation of ammonium by symbiotic Chlorella (Chlorophyta). J Phycol 32:839-846

Molloy CJ, Syrett PJ (1988) Interrelationships between uptake of urea and uptake of ammonium by microalgae. J Exp Mar Biol Ecol 118:85-95

Norici A, Giordano M (2002) Anaplerosis in microalgae. Recent Res Devel Plant Physiol 3:153-164

Nunez VJ, Voltolina D, Nieves M, Pina P, Medina A, Guerrero M (2001) Nitrogen budget in Scenedesmus obliquus cultures with artificial wastewater. Bioresour Technol 78:161-164

Pavlova EA, Romanova AK, Demidov ED (1994) Assimilation of inorganic nitrogen by photosynthesizing Chlorella cells. Russ J Plant Physiol 41:200-207

Piorreck M, Baasch K-H, Pohl P (1984) Biomass production, total protein, chlorophylls, lipids and fatty acids of freshwater green and blue-green algae under different nitrogen regimes. Phytochemistry 23:207-216

Prescott GW (1978) How to know freshwater algae, 3rd edn. McGrawHill College, Dubuque

Rees TAV (1989) The green hydra symbiosis and ammonium II. Ammonium assimilation and release by freshly isolated symbionts and cultured algae. Proc Roy Soc Lond B 235:365-382

Rodolfi L, Zittelli GC, Bassi N, Padovani G, Biondi N, Bonini G, Tredici MR (2009) Microalgae for oil: strain selection, induction of lipid synthesis and outdoor mass cultivation in a low-cost photobioreactor. Biotechnol Bioeng 102:100-112

Roon RJ, Levenberg B (1968) An adenosine triphosphate-dependent, avidin-sensitive enzymatic cleavage of urea in yeast and green algae. J Biol Chem 243:5213-5215

Schuller KA, Plaxton WC, Turpin DH (1990) Regulation of phosphoenolpyruvate carboxylase from the green alga Selenastrum minutum: properties associated with replenishment of tricarboxylic acid cycle intermediates during ammonium assimilation. Plant Physiol 93:1303-1311
Sedlak R (ed) (1991) Phosphorus and nitrogen removal from municipal wastewater: principles and practice, 2nd edn. Lewis, New York

Shiraiwa Y, Goyal A, Tolbert NE (1993) Alkalization of the medium by unicellular green-algae during uptake of dissolved inorganic carbon. Plant Cell Physiol 34:649-657

Sialve B, Bernet N, Bernard O (2009) Anaerobic digestion of microalgae as a necessary step to make microalgal biodiesel sustainable. Biotechnol Adv 27/4:409-416

Thacker A, Syrett PJ (1972) The assimilation of nitrate and ammonium by Chlamydomonas reinhardi. New Phytol 71:423-433

Trainor FR, Cain JR, Shubert LE (1976) Morphology and nutrition of the colonial green alga Scenedesmus: 80 years later. Bot Rev 42:5-25

Turpin DH, Bruce D (1990) Regulation of photosynthetic light harvesting by nitrogen assimilation in the green alga Selenastrum minutum. FEBS Lett 263:99-103

Turpin DH, Vanlerberghe GC, Amory AM, Guy RD (1991) The inorganic carbon requirements for nitrogen assimilation. Can $\mathrm{J}$ Bot 69:1139-1145

Vanlerberghe GC, Schuller KA, Smith RG, Feil R, Plaxton WC, Turpin $\mathrm{DH}$ (1990) Relationship between $\mathrm{NH}_{4}{ }^{+}$assimilation rate and in vivo phosphoenolpyruvate carboxylase activity: regulation of anaplerotic carbon flow in the green alga Selenastrum minutum. Plant Physiol 94:284-290

Voltolina D, Cordero B, Nieves M, Soto LP (1999) Growth of Scenedesmus sp. in artificial wastewater. Bioresour Technol 68:265-268

Widjaja A, Chien CC, Ju YH (2009) Study of increasing lipid production from fresh water microalgae Chlorella vulgaris. J Taiwan Inst Chem Eng 40:13-20

Xin L, Hong-ying H, Ke G, Jia Y (2010) Growth and nutrient removal properties of a freshwater microalga Scenedesmus sp. LX1 under different kinds of nitrogen sources. Ecol Eng 36:379-381

Yun Y-S, Lee SB, Park JM, Lee C-I, Yang J-W (1997) Carbon dioxide fixation by algal cultivation using wastewater nutrients. J Chem Technol Biot 69:451-455 